\title{
The Origins of Intermodernism in Ford Madox Ford's Parallax View
}

\section{Nick Hubble}

I should say it started just before the last war, when Ford Madox Ford, the editor of the English Review, met D.H. Lawrence and saw in him the portent of a new class finding expression in literature.

- George Orwell, 'The Proletarian Writer'

Kristin Bluemel's recent book George Orwell and the Radical Eccentrics:

Intermodernism in Literary London (2004) proposes the category of 'intermodernism' to describe the work of a circle of writers around George Orwell: Stevie Smith, Mulk Raj Anand and Inez Holden. These writers enjoyed a distinctive vantage point stemming from the ambiguous position of being simultaneously inside and outside the group being described; as is the case with Smith's relationship to her fellow suburbanites, Anand's to his fellow Indian nationalists and Holden's to her fellow wartime workers, and also for all of them in their relationships with the London literary intelligentsia. For example, in Night Shift (1941), Holden employed her wartime experience of working in a factory to render working-class lives through fictionalised autobiography - much as Orwell did in The Road to Wigan Pier (1937) by including the wealthy 'Feather' among her cast of female factory workers as a point of identification for middle- and upper-class readers. However, in There's No Story There (1944), she was able to dispense with the 'Feather' figure while still retaining the insights stemming from a dual perspective, thus generating a text which simultaneously celebrated both 'the imaginative lives of readers and the interests of the workers themselves' (p.133). It is precisely this dual perspective which sets intermodern narrative free from the association of high or low (or middlebrow) culture and gives it the potential to make things happen in the world. Similarly, Bluemel demonstrates that it is Anand's status as both insider and outsider simultaneously member of the intellectual elite and disempowered colonial subject that frees his autobiographical narratives from 'the constraints of modernism': 'Instead of emerging from the tradition of the stream-of-consciousness novel, with its debt to the alienated, romantic hero of bourgeois realism, Anand's nonfiction heroes are, ironically, empowered and enlivened by the most prosaic generic claims of their narratives' (p.93). 
The motivation for Bluemel's book is dissatisfaction with 'the bad habits and intellectually limiting framework that have blinded us to the diversity and dynamism of literature connecting the 1930s and 1940s' (165). Although she takes good care not to say so bluntly, it is apparent that the intellectually limiting framework she is referring to is the elevated status 'Modernism' has attained in contemporary academic discourse. This dominance is now so firmly embedded in literary studies that it has created a real problem in how to categorize any figure from the first four decades of the century not central to the canonical formulation of Modernism: how do you explain the decision of technically accomplished writers not to be self-conscious modernists? What else is there to do but regard this as willful eccentricity? This is the context for Bluemel's designation of her set of non-modernist writers as radical eccentrics in order to highlight how their occupation of positions 'on the borders of multiple literary circles and cultural institutions' should not be seen as evidence of marginalization (or, indeed, exceptional status in the case of Orwell) but as a challenge to the 'often oppressive assumptions about art and ideology - about standard relations between literary forms and sex, gender, race, class, and empire that dominate English culture at every point of the political spectrum' (7-8).

Underlying these assumptions is the idea that literary culture can be divided between, what Virginia Woolf described in a famous reference to the unholy materialist triumvirate of Mr Wells, Mr Bennett and Mr Galsworthy, writing that makes 'the trivial and the transitory appear the true and the enduring' and writing that is 'concerned at all costs to reveal the flickerings of that innermost flame which flashes its messages through the brain', ${ }^{2}$ as in the case of the spiritual Mr Joyce. This division has long since become enshrined in critical orthodoxy so that, for example, a work such as Malcolm Bradbury's The Modern British Novel, takes as self-evident the difference between "the "Modern", experimental and avant-garde ... [and] the "Contemporary", which is fiction and literary art at its familiar work of exploring the world as in general we see it, and the way we live now' (xiii). It is exactly this attitude which has led to the privileged status of a modernist canon within academic analysis of twentieth-century literature because scholars seeking to work beyond those boundaries effectively subordinate themselves into a hierarchical system that forever condemns their efforts to the realms of the transitory; unless, that is, they explicitly contest the foundation of that hierarchy. Of course, ironically, this was what Woolf was doing in the aftermath of the First World War: contesting a hierarchy that 
privileged the mimetic social realism of Wells, Bennett and Galsworthy as the correct way of writing about the world at that time. Her famous essays, 'Modern Fiction' and 'Mr Bennett and Mrs Brown', deconstruct the trio's social realist techniques to show that what is represented as authentic presence is actually an absence of life: 'Life is not a series of gig lamps symmetrically arranged; life is a luminous halo, a semitransparent envelope surrounding us from the beginning of consciousness to the end. ${ }^{3}$ Taken in context, this was a perfectly understandable strategy for opening the space necessary for a new literary voice to express itself; but this does not mean that her judgment should stand for all time as the last word on the subject. It should not be considered an act of heresy to suggest that, actually, Woolf was wrong: life is always perceptible as either gig lamps or luminous halo depending on perspective; rather as in quantum physics, matter consists of waves or particles depending on perspective.

In The Parallax View, Slavoj Žižek describes such confrontations of 'two closely linked perspectives between which no neutral common ground is possible' as parallax gaps. ${ }^{4}$ While the standard definition of parallax is 'the apparent displacement of an object (the shift of its position against a background), caused by a change in observational position that provides a new line of sight' (17) - the simple way is to hold your finger up in front of your eyes and first shut one and then the other: your finger is undergoing a parallax shift - the added philosophical twist is that the observed difference is not simply "subjective" but that the "epistemological" shift in the subject's point of view always reflects an "ontological" shift in the object itself" (17). That is to say that what is revealed to us is the object's non-coincidence with itself, its parallax gap. Žižek's main point, which he constantly reiterates and elaborates, is that it is the parallax gap or shift - the difference seen in the object as a result of the shift of perspective - which constitutes the Real, rather than either a presence or an absence. He is quick to point out that the parallax Real differs from the Lacanian Real:

The parallax Real is thus opposed to the standard (Lacanian) notion of the Real as that which 'always returns to its place' - as that which remains the same in all possible (symbolic) universes: the parallax Real is, rather, that which accounts for the very multiplicity of appearances of the same underlying Real - it is not the hardcore which persists as the Same, but the hard bone of contention which pulverises the sameness into the multitude of appearances (26) 
However, while the Real is revealed as the shifting product of a multitude of symbolic formulations, this is often further concealed by the tendency of the two levels involved in the parallax shift to be radically asymmetric: 'One of the two levels appears to be able to stand on its own, while the other stands for the shift as such, for the gap between the two. In other words, Two are not simply One and One, since Two stands for the very move/shift from One to Two' (42). Returning to the obviously asymmetric relationship between Modernism and social realism, it can now be seen that what is concealed by the privileging of Modernism over social realism, is that 'Modernism' is not an authentic presence, but the shift itself, and therefore that it necessarily incorporates interconnections with social realism within itself. The advantage of the term 'Intermodernism' is that it explicitly acknowledges these interconnections.

Elsewhere, I have proposed that William Empson should be included among the radical eccentrics alongside Bluemel's four main examples of Orwell, Smith, Anand and Holden; ${ }^{5}$ not only was he a mutual friend who moved in the same circles as them, but also his concept of comic primness, as outlined in Some Versions of Pastoral (1935), provides a theoretical model for understanding how the dual perspective in their work generates the narrative freedom central to the concept of intermodernism. Empson defines comic primness as "the double irony in the acceptance of a convention' (170). One of the examples he provides is that of 'ironical humility, whose simplest gambit is to say "I am not clever, educated, well born" or what not (as if you had a low standard to judge by), and then to imply that your standards are so high in the matter that the person you are humbling yourself before is quite out of sight' (171). As Empson explains, the effect of the 'important' classing themselves with the 'lowest' in this manner is to raise standards not lower them; as once the conventions of education and social rank have been valued so highly that there is plenty of space left below in which to live freely, the immediate ironic rejection of the same conventions radically expands this sphere of free actions.

Writing in the middle of a decade when siding with the working class had become a political obligation for a generation of writers, Empson raises the possibility of such solidarity being not only a duty but also a pleasure - a combination which, following Žižek, might be termed the Empson parallax because it turns on the non-identity of pleasure and duty rather than any ground in common between the two. ${ }^{6}$ There is no sense in Empson's formulation of a higher realm of freedom engaged by direct 
contact with things in themselves - a possibility which Žižek, following Kant, notes "would deprive us of the very "spontaneity" which forms the kernel of transcendental freedom: it would turn us into life-less automata - or, to put it in today's terms, into "thinking machines.", Empson used his own day's terms to dismiss a similar threat inherent to the socialist realist concept of proletarian literature: 'Once you have said that everything is One it is obvious that literature is the same as propaganda' (24). He went on to clarify his own position: 'I do not mean to say that the philosophy is wrong; for that matter pastoral is worked from the same philosophical ideas as proletarian literature - the difference is that it brings in the absolute less prematurely' (25). In other words, simultaneously holding the two perspectives, whether considered as 'high' and 'low' or duty and pleasure, generates the productive tension of a parallax shift: the 'low' is perceived as including the shift from the 'high'; pleasure as including the shift from duty. Awareness of the shift forces the ironist 'into isolation by sheer strength of mind, and so into a philosophy of Independence' (171).

The essay on 'Proletarian Literature' with which Empson begins Some Versions of Pastoral appears, therefore, to be a rejection of the possibility of proletarian literature, as his biographer John Haffenden argues. ${ }^{8}$ However, as I have suggested elsewhere, the essay's prominence in the book implies that Empson did not find the whole topic a red herring; rather, his point is that the fact that the artist can never be at one with the worker does not so much prove the impossibility of producing pure proletarian art, as demonstrate that any actual creation of work intended as proletarian literature is necessarily the product of a dual perspective. ${ }^{9}$ This insight chimes with a sophisticated Marxist understanding of the proletariat, as expressed by Žižek in terms of a parallax shift: 'in the class struggle between bourgeoisie and proletariat, the proletariat stands for the struggle as such' (42). Combining the arguments of Empson and Žižek, it is possible to argue that dual perspective is converted into a parallax shift enabling freedom or independence through the 'trick' of comic primness, which can be 'followed through a historical series' (25). Some Versions of Pastoral represents 'proletarian literature' as the latest stage, following other manifestations ranging from the metaphysical poets to Alice in Wonderland, of an ongoing transition from a select to a universal audience for the pastoral generation of independent agency. The best example of work realising the potential Empson saw in 'proletarian literature' would be the books Orwell wrote in the period just after the publication of Some Versions of Pastoral. In The Road to Wigan Pier (1937), he describes the benefits he gained from 
immersing himself in the world of tramps and ends with an injunction to his middleclass readership to follow suit:

... we of the sinking middle class - the private schoolmaster, the halfstarved free-lance journalist, the colonel's spinster daughter with $£ 75$ a year, the jobless Cambridge graduate, the ship's officer without a ship, the clerks, the civil servants, the commercial travellers, and the thricebankrupt drapers in the country towns - may sink without further struggles into the working class where we belong, and probably when we get there it will not be so dreadful as we feared, for, after all, we have nothing to lose but our aitches. ${ }^{10}$

Orwell's next but one book, the novel Coming Up for Air (1939), employs the different but related technique of locating his own attitudes in suburban everyman George Bowling, acknowledged in the text by Bowling's description of himself as 'fat, but ... thin inside', before leaving his readership with a multiple-choice ending that invites them to put themselves in Bowling's shoes and work out the correct response for him. ${ }^{11}$ Orwell's link to his readership is not generated by an attempt to be at one with them, but precisely by not being at one with himself, thus allowing them to recognise their own non-identity with themselves. Subsequently, he went on to explicitly echo Empson by suggesting that the only value of 'proletarian literature' as a term was 'as a label for a rather heterogeneous literature belonging to a transition period', by which he meant the transition to a classless society. ${ }^{12}$

Understood thus, successful 'proletarian literature' can be seen as an example of intermodernism. Therefore, returning to the epigraph of this essay and Orwell's argument that proletarian literature originated with the meeting of Ford Madox Ford and D.H. Lawrence, it becomes possible to attempt to trace the existence of intermodernism back to that meeting. Ford's own account in Portraits from Life (1937), states that he first came across Lawrence through reading the manuscript of 'Odour of Chrysanthemums' and realising after the first paragraph that he had a genius who could write about the lives of the other half. ${ }^{13}$ Max Saunders suggests, following the argument of Lawrence's biographer John Worthen, that in reality they met before this occasion and that it was Ford who suggested to Lawrence that he should write from his knowledge of the mining community when writing 'Odour of Chrysanthemums' and his first play, A Collier's Friday Night: 'Their subject-matter and use of dialect are almost unprecedented in his oeuvre, but characterize his major 
subsequent work. ${ }^{14}$ Much could be said about this - not least that Lawrence, like those successful working-class writers who followed him, captured the reality of that experience not by recourse to his own authenticity but by recognising and then fully mapping out the extent of his non-identity with working-class life - but what I want to demonstrate in this paper is that the origins of what Orwell meant by 'Proletarian Literature' lie in Ford's writing, itself, independently of Lawrence and it was precisely this already existing tendency which allowed him to 'discover' Lawrence.

In a previous paper of mine, 'Beyond Mimetic Englishness: Ford's English Trilogy and The Good Soldier', I argue: 'Unlike Virginia Woolf, whose opposition to the forces of social mimesis is clearly reflected in her attacks on Wells, Bennett and Galsworthy, Ford seems always to have been aware that a modernist identity could not be constructed in opposition to modern mass society, but only in conjunction with it. Ford's personal desire was not to oppose the social mimesis of the masses but to go beyond it: an outcome he achieved in The Good Soldier. ${ }^{15}$ My case was that Dowell's assertion that 'I can't conceal from myself the fact that I loved Edward Ashburnham - and that I love him because he was just myself' $(G S, 227)$ is 'deeply and knowingly ironic because the Ashburnham that Dowell loves is his own invention: it is not the empty-headed "good" soldier who occasionally shows through, but a courageous, virile figure whose agency both leads to, and derives from, Dowell's own agency as narrator'. ${ }^{16}$ I went on to argue that Dowell achieves this narrative trick by adopting an 'Ironical Humility' in keeping with Empson's understanding of 'Comic Primness'; but this agency can also be seen as a function of the parallax gap between Ashburnham and Dowell, where 'Dowell' stands for the very shift between Ashburnham and himself. Ashburnham who appears to be the active subject turns out to be an empty vessel filled with the equivalent of Woolf's 'the trivial and the transitory' and as such exhibits the non-coincidence of the object. However, it is exactly as an object that his passivity becomes active by - paraphrasing Žižek - moving, annoying, disturbing and traumatising Dowell, whereupon this activity constitutes the active subjecthood of Dowell. Therefore, The Good Soldier demonstrates how modernist identity is formed not by acting in opposition to the passive social mimesis supposedly characteristic of mass democracy, but by going beyond passive subjecthood to the point where the active challenge posed by the object transforms subjectivity into an active state. 
But what would make the conclusion of the novel specifically intermodern as opposed to simply being a demonstration of how modernist identity is not authentic presence but the actual parallax shift from passive imitation to active subjectivity? Or, to put this question another way, aside from the structural similarity, what concretely links Dowell's (supposedly) passive imitation with the (supposedly) passive social mimesis of mass democracy? The connection can be seen in the existence of an early, brief version of the story of The Good Soldier told as an anecdote in The Spirit of the People, the final volume of Ford's English trilogy. Here, a gentleman takes indefinite leave of his young ward, with whom he has fallen in love, without a word being spoken between them. Ford views this incident from two radically different but linked perspectives: as an appalling manifestation of English repression and as an example of the evolution of English manners. He describes this parallax gap as arising from the puritan divorce of principle from poetry which originated with the Reformation, as portrayed in the Fifth Queen trilogy. In this context, as I argue in 'Beyond Mimetic Englishness', the governing project of the English trilogy is to suggest that the emergence of mass society offers the possibility for some form of reconciliation between principle and poetry and, therefore, the renewed possibility of human agency, because the mass passive imitation of the leisured aristocratic class which it generated creates a utopian fantasy relationship with the residual individualism and poetic common sense of the idea of the 'Countryside' still embodied by that aristocratic class. In more practical terms, such reconciliation also promised an end to the cruel disjunction between sexuality and manners, which Ford kept falling so spectacularly foul of in his personal relationships. While The Good Soldier does not resolve this issue, it clearly highlights it and, in the negative form of Dowell's plaintive remark that 'society can only exist if the normal, if the virtuous, and the slightly deceitful flourish' $(G S, 227)$, expresses the utopian desire that things be otherwise. Therefore, it is not fanciful to suggest that Ford was pursuing his own intermodern project in which if the end point was not exactly classless society as commonly understood, it would at least involve everyone getting on together in the absence of sexual hypocrisy. The Good Soldier was an important stage on the road to fulfilling this project, which can be traced in sequence through several of his novels.

In A Call (1910), the two main male characters, Robert Grimshaw and Dudley Leicester, are also doubled in a manner similar to Dowell and Ashburnham in The Good Soldier. The model for these relationships was the real life friendship of Ford 
and his paternalist Tory friend, Arthur Marwood. Saunders notes that 'Ford liked to think of Marwood as his opposite - stable, a member of the 'county' establishment as well as his double. Many of his descriptions hover between a sympathetic identification on the one hand, and on the other seeing himself and Marwood as being at opposite ends of human creation. ${ }^{17}$ The meaning of this relationship to Ford can perhaps be seen as the key expression of his sense of duality, which extends beyond the uncanniness of the doubles which infect fin-de-siecle literature, to an understanding of intersubjectivity as the precondition for conscious existence. For this reason, Saunders takes Ford's duality as the focus of his biography: particularly the relationship between Ford's own dual perspective - 'seeing himself from outside while describing his deepest interiority' - and the dual effect he produces in the reader 'of a felt discrepancy between what we read and what we know (or suspect)' ${ }^{18}$ If Ford's awareness of the non-coincidence of his own subjectivity may be seen as an exemplary demonstration of his parallax view, so also can Saunders's biography be seen as an exemplary demonstration of the parallax Real in which the very multiplicity of appearances of Ford are never reduced into the false consistency of the Same but are instead allowed to chart 'the hard bone of contention which pulverises the sameness into the multitude of appearances': the duality of non-identity. The relationship with Marwood, however, offered Ford a similar opportunity at the individual level to the one he recognised as being created by the rise of mass society at a collective level: it enabled poetry and principle to be brought into productive tension through a parallax shift. The 'multiplicity of political personalities' inhabited by Ford in the 1890s were resolved by the mutual encounter with Marwood into the ambiguously poised position of Tory anarchist. ${ }^{19}$ At which point, it is worth noting that in 1930, on Orwell's full emergence into the world of politics and letters following his formative experiences in the Imperial Burma Police and as a tramp, he announced himself to the staff of the socialist Adelphi as a Tory anarchist, having undergone a similar parallax shift. ${ }^{20}$

Like Ashburnham, Leicester, the Marwood character in A Call, is an empty vessel; only we know this from early in the book and the plot partly revolves around Grimshaw's attempt to provoke him into an active subjectivity. Grimshaw loves two women, Pauline and the temporally unavailable Katya, but opts to marry Pauline to Leicester and wait for Katya. Subsequently, Leicester gets led astray by his ex-fiancée and inveigled into her house at night but there he answers the phone and because the 
caller recognises his voice, is plunged into a catatonic state of guilt. We eventually learn that the caller is, of course, Grimshaw, who had seen them in the street, and hopes in some way to trigger Leicester into a more active partner for Pauline.

However, the practical consequence is that he is thrown more into Pauline's company leading to the eventual realisation that it is she with whom he longs to live permanently and not Katya. This melodramatic reversal is completed when Grimshaw agrees to Katya's demand that they should live together unmarried, whereupon she says that in that case they can marry after all, prompting his disconsolate reply: 'So that you get me both ways'. ${ }^{21}$

In discussing the sadness and waste of passion in The Good Soldier, Saunders cites Michael Ignatieff's description of the horror 'rooted in the primal insatiability of all human desiring, in the inability of any actual objects to satisfy our initial desire to regain a oneness with the world'. ${ }^{22}$ However, we know this 'oneness' to be illusory: the self cannot even be at one with itself because it is always non-identical with itself. Perhaps this recognition is the true source of the desolate horror experienced by Grimshaw at the end of the novel; the acknowledgment that Katya can get him both ways making it no longer possible for him to avoid his own essential duality, which he has hidden from himself by transposing it into the apparently simultaneous love for two women. Therefore, his attempt to escape this duality through the altruistic renunciation of Pauline to Leicester was always doomed to failure. This does not mean, though, that his marriage to Katya is necessarily as appalling as Saunders implies. ${ }^{23}$ The very fact the book - not including the epistolary epilogue - ends with Katya's claim to have him 'every way and altogether' $(A C 158)$ at least holds out the promise for both of them of getting beyond duality to an intersubjective existence. Maybe this was not Ford's intention but it is certainly tempting to suggest that he was happier in his personal life during those periods when he was prepared to let women get him both ways, rather than those in which he resisted in the name of an illusory oneness.

Saunders discusses the similarity between the horror of the endings of A Call and Henry James's The Wings of the Dove and suggests that the James-like portrayal of Grimshaw with dachshund is repayment for James basing Merton Densher upon Ford or, at least, Ford's conviction that this was the case. ${ }^{24}$ Interestingly, Žižek discusses The Wings of the Dove in an 'Interlude' within The Parallax View entitled 'Kate's Choice, or, The Materialism of Henry James', in which he argues that Kate Croy is 
the novel's true ethical hero. ${ }^{25}$ She chooses to take neither Densher nor Milly's money - the alternatives Densher tries to force on her - because she understands that either option would be an acceptance of the false position adopted by Densher towards Milly. According to Žižek, Densher is not refusing to profit from Milly’s death because he doesn't love her and is therefore 'unworthy of her gift, but because he does love her - not while she was alive, but from the moment she died. He fell in love with her gesture of dying for him and Kate... ${ }^{26}$ This false position or fake love is reminiscent of Grimshaw's sudden discovery of his love for Pauline; only he falls in love not with the sacrificial gesture of another but with his own renunciation of Pauline at exactly that point when the consequences of his own actions bring home to him the true significance of what he has done. It is perhaps possible to suggest that Ford was writing Grimshaw as a recuperation of James's writing of him as Densher and, that by taking over and altering Densher's failings in this way, he was therefore able to take control over the representation of horror. Thus, while horror is clearly experienced by Grimshaw at the end of $A$ Call, it is also acknowledged by him much earlier in the book when, rather as Dowell critiques society in The Good Soldier, he expresses it as a critique of civilisation:

'We're all - all of us, in our class and our day, doing the same thing. Every one of us really wants the moon, and we've got somehow to get on with just the earth, and behave ourselves. I suppose what I really want is both Katya and Pauline ... but I've got to sacrifice one of them to the amenities of a civilization that's pleasant enough, and that's taken thousands of years to bring together ...' (AC 23)

Žižek defines the greatness of James as lying in his preparedness to confront unflinchingly the deadlock - the horror - when the two sides of a parallax view cannot be brought together. Thus, 'while [James] fully assumes this break of modernity [the effect of capitalist modernization on ethical life] and emphasizes the falsity of any retreat to old mores, he also avoids ethical relativism and historicism, that is the relativization of norms and ethical values to an expression of some more fundamental underlying (economic, psychological, political) historical process' (126). ${ }^{27}$ Žižek goes on to conclude: 'the uncertainty itself, the lack of a fixed socioethical frame of reference, far from simply condemning us to moral relativism, opens up a new 'higher' field of ethical experience, that of intersubjectivity, of the mutual dependence of subjects, of the need not only to rely on others, but also to recognise 
the ethical weight of others' claims on me'. ${ }^{28}$ Something of this is eventually opened up by A Call, when Pauline strips away Grimshaw's fixed socio-ethical frame of reference: “"Robert," she said gravely, "who is of our day and our class? Are you? Or am I? Why are your hands shaking like that, or why did I just now call you 'my dear'? We've got to face the fact that I called you 'my dear'. Then, don't you see, you can't be of our day and our class ..." (AC 148). Indeed, Pauline might be regarded as the novel's Jamesian ethical hero, who eventually comes to see through Grimshaw's fantasy of renunciation and is able to confront the consequences unflinchingly: 'You love me, and you have ruined all our lives. But it doesn't end, it goes on. We fly as far asunder as the poles, and it goes on for good' (AC 150). Yet this stance is the source of an exchange far more appalling than that which closes the novel:

'So that now,' she retorted with a little bitter humour, 'what you've got to do is give Katya a good time and go on waiting for me.'

'Till when? He said with a sudden hot eagerness.

'Oh,' she said, 'till all the ships that ever sailed come home; till all the wild oats that were ever sown are reaped; till the sun sets in the east and the ice on the poles is all melted away. If you were the only man in all the world, my dear, I would never look at you again.' (AC 150-1)

What is exposed here is the flaw of the Jamesian position of unflinchingly confronting the horror. While the radical break from tradition, historicism and ethical relativism, as identified by Žižek, might well be the necessary precondition for a 'higher' intersubjectivity, there is rarely any suggestion in the work of James as to how this is going to be achieved. James's heroines such as Kate Croy and Isabel Archer in The Portrait of a Lady free themselves, like Pauline in A Call, at the cost of making the horror they encounter into a permanent state of existential being. While this could perhaps be read as a proto-feminist protest; the underlying authorial position is the misogynist assumption that there is no meaning outside the patriarchal order. Ford clearly thought otherwise as can be seen from his support for the suffragettes: 'personally, I want to get hold of a woman that I can trust better than any man ... I am sick of women as they are. I want them changed; this is why I want women to have the vote. ${ }^{29}$ Of the two main female characters in A Call, it is Katya, with her psychoanalytical understanding, who embodies the possibility of the change Ford supported and the ethical choice she makes which opens up this possibility is her decision not to marry. It now becomes easier to see the consequence of Ford rewriting 
James: not only is the "negative feminine gesture" ${ }^{30}$ allowed to signify a genuinely alternative order, but the entire frame of reference is inverted so that, anticipating Parade's End, the narrative turns on a man's struggle to orientate himself towards this female order rather than vice versa.

For A Call to succeed in realising this new intersubjectivity at the level of representation, it would seem that Grimshaw must break free of his own fantasy of renunciation, which he has fallen in love with in the shape of Pauline. Does this require a radical act of negation or, in the manner that Roland Barthes argued the only way to contest myth was with a rival myth, does it require a rival fantasy? The answer must lie in the affirmative for both cases. Grimshaw's fantasy is negated, as we have seen, by Pauline making it into an impossibly epochal renunciation fantasy of her own; but this moment of exchange both enables and is broken by Grimshaw's confession that he made the call of the title. The call itself must be seen as the act of negation stemming from the transference of Grimshaw's ethical disgust with his own actions onto Leicester. By admitting making the call, Grimshaw regains his ethical agency and breaks free of the web of false positions he has woven around himself. He is now in a position to see how so much of his life has been an imitation of the life of an English gentleman, that his passion for Katya is equally an imitation of passion and that, despite 'having been trained in the English code of manners never to express any emotion at all' ( $A C$ 154), he does have emotions. That this leads to a relatively limp conclusion which Ford tinkered indecisively with, ${ }^{31}$ is a measure of the extent to which Ford remained at that time in thrall to a notion of the Real rather than the parallax Real. As suggested above, the symbolic structure of the novel permits the creation of a radically different intersubjective experience between Grimshaw and Katya, but this is left as only a faint possibility in what is otherwise presented as a sad story. However, it structurally prefigures the even sadder story of The Good Soldier in which the decisive radical moment, analogous to Grimshaw's confession, is Dowell's admission that he loved Ashburnham because he was himself.

The reason why The Good Soldier works so much better than A Call, is that Dowell is able to renew and transform his imitative fantasy in the same movement by which he radically breaks from it. His awareness of being simultaneously a copy of, and yet not the same as, Ashburnham, becomes the generator of his agency because it shows him that he can act differently. Of course this latter novel not only benefited from the experience of writing the earlier one, but also from the reflection enabled by the 
passage of time. The various versions of $A$ Call were written over the period during which both Ford's marriage and friendship with Marwood were ending and his relationship with Violet Hunt was beginning and so the recognitions and understandings it fictionalises are no doubt those Ford felt most strongly at the time. In particular, the relationship with Marwood must have seemed a product of selfdelusion after hearing about Marwood's improper advances to his wife. ${ }^{32}$ Yet, ultimately, the fictional reworkings of this relationship created his greatest books because through repetition he was able to map out, in the manner of the parallax Real, a non-identical Marwood-Ford identity - most notably Tietjens in Parade's Endwhich enabled him to continue to attempt to fulfil the utopian fantasy, embodied in the actual relationship with Marwood, of bringing poetry and principle into productive tension.

Žižek cites Sigi Jöttkandt's argument that Milly in The Wings of the Dove dies in order to sustain her desiring fantasy, but implies that this sacrifice in order to continue to dream is not in itself ethical, indeed quite the opposite, because it doesn't traverse the fantasy and move beyond it. ${ }^{33}$ However, he seems to ignore this insight when trying to illustrate a point with a brief reference to another novel:

Take the final reversal in Edith Wharton's The Age of Innocence, in which the husband who for many years has harboured an illicit passion for the Countess Olenska is, after his wife's early death, free to join his love; however, when, on the way to her, he learns from his son that his young wife knew about his secret passion all the time, his union with Countess Olenska becomes impossible for him. ${ }^{34}$

It is possible to read the novel quite differently and conclude that the late point on which it turns is Newland Archer's realisation that to see the Countess again would be a betrayal of his life choice which has been to outwardly conform to the dictates of respectable society while inwardly attempting to live up to his utopian fantasy of another country free of social and sexual hypocrisy. This could be seen as exactly that sacrifice in order to continue to dream which Žižek condemns as unethical, if it were not for the fact that the disruptions in the narrative caused by the eruptions of the utopian fantasy so clearly open up spaces for an alternative order to emerge. The Age of Innocence is haunted by the birth pangs of the future as, for example, in the passage where Archer, for once alone with the object of his desire, is frustrated by the unexpected arrival of Julius Beaufort and experiences a ghostly sense of 
disembodiment: 'at this opening Madame Olenska twisted the talk away to the fantastic possibility that they might one day actually converse with each other from street to street, or even - incredible dream! - from one town to another ... and the question of the telephone carried them safely back to the big house. ${ }^{, 35}$ Therefore, Archer's sacrifice in the closing scene of the novel is ethical because he realises that to see the Countess would be a retreat to pure fantasy undermining the more liberated future he has helped to create by traversing that fantasy. It is this particular quality of Wharton's work, overlooked by Žižek in his focus on James, that also underlies Ford's fictional achievements and which should be seen as an advance on James. One utopian element in A Call concerns, as we have seen, the possibility of a new intersubjective relationship between the sexes but another exists at a deeper, unconscious level. Let us return to the moment preceding Grimshaw's outburst that he really wants both women. Ellida, Katya's sister, has just realised that Grimshaw has 'given' Pauline to Leicester even though he loves her:

She stopped, and then she uttered suddenly: 'Oh, Robert, you oughtn't to have done it; no good can come of it.'

He turned upon her sharply. 'Upon my word,' he said, 'you talk like an old-fashioned shopkeeper's wife. Nothing but harm can come of it! What have we arrived at in our day and our class if we haven't learnt to do what we want, to do what seems proper and expedient - and to take what we get for it?

'Oh, our day and our class,' Ellida said slowly. 'It would be better for Pauline to be the old-fashioned wife of a small shopkeeper than what she is ...' (AC 21-2).

The repressed insight of $A$ Call is that one way out of the horror is to become like a shopkeeper.

This repressed content emerges with spectacular consequences in The New Humpty Dumpty (1912), published under the pseudonym of Daniel Chaucer. Written at a time when Ford's marriage had finally come to its messy end, the friendship with Marwood was over and his editorship of the English Review had been lost, Ford represents himself as the persecuted but altruistic Count Macdonald, encumbered with an estranged spouse described as a typical 'English shopkeeper's wife' (40) and a best friend, Mr Pett - a thinly veiled caricature of that son of a shopkeeper, H.G. Wells - a 'product of [the] Education Act of 1870' (27), who 'had commenced his career of 
public usefulness as booking-office clerk at a suburban station' (314) before rising through the ranks of the Fabians. ${ }^{36}$ Early in the book, Pett outlines his program:

'The whole world's just engaged in manufacturing middle-class Englishmen ...'

Lady Aldington said: 'That's very interesting, now.'

'It means,' Mrs Pett said, 'that we're gradually approaching to a unity of mankind. We're bringing the whole word to one standard. Then the brotherhood of man will begin.'

'When we're all English middle-class?' Lady Aldington asked.

'Your ladyship means lower middle-class,' Mr Pett said. (NHD 17-8)

Here, the horror being confronted by the novel is close to the deadlock Žižek identifies in James's The Princess Casamassima: 'the impossibility of choosing between the rights of the dispossessed and high culture' ${ }^{37}$ In the first half of the novel, Ford succeeds in opening up the higher ethical field of intersubjectivity in a great pantomime of class, which, rather than rendering everyone lower middle-class in the sense implied by Pett, registers the full parallax shift between the aristocracy and the lower-middle class to create something like a classless society in which Macdonald's servant-less wife can send the Duke of Nottingham 'into her kitchen to fetch the kettle for tea' (NHD 46). However, the second half of the novel loses sight of this utopian fantasy and yet still falls foul of Žižek's insistence that there should be "no directly existing "ethical substance", the only "actually existing" thing is the incessant activity and interaction of individuals, and it is only this activity that keeps it alive' ${ }^{38}$ Macdonald's adherence to a convoluted moral code marks a regression into a fantasy of persecution and undoes the intersubjectivity of the first half as he gradually breaks relationships with Pett and the others (thus replaying the end days of the English Review) before eventually dying for high culture: shot for insulting the author of The Count of Monte Cristo.

As in all Ford's books, the real life influences for these characters and relationships are overdetermined so that the relationship of Pett to Macdonald is not just that of Wells to Ford but also that of Ford to Marwood. In other words, Pett symbolically represents the reformist lower-middle-classness of a shift between Wells and Ford; Macdonald represents the Tory anarcho-paternalism of a shift between Marwood and Ford. While by dying for his altruism, the latter appears to be privileged by the text, we can also interpret his death as the necessary elimination of ethical substance in 
order to free the intersubjective writer to go on to write The Good Soldier. Here, the comparable relationship is obviously that between Dowell and Ashburnham but Ford's advance, as we have seen, is to allow Dowell to stand for the very shift between Ashburnham and himself and thus become an active subject. This development, in turn, enables Parade's End to be centred on a single figure rather than a doubled pairing. Of course, this is not to say that Tietjens does not have relationships with figures such as Macmaster and McKechnie but these are not necessary to represent his non-identity and duality to the reader, who like the suffragette Valentine Wannop is almost immediately affected by him 'queerly as being both in and out of place'. ${ }^{39}$ The novels turn on Tietjens first becoming conscious of his own duality and then on his struggle to realise the potential agency entailed by that. Therefore, the central parallax shift is not between two doubled characters as is the case of much of Ford's earlier fiction but between a younger and an older Tietjens.

There is no causal progression from the past to the future but a gap which has to be repeatedly opened in the present to allow an alternative order to emerge through an uneven process of superimposition. One analogy for bridging these sundered states of being is provided, as we have seen in A Call and Edith Wharton's The Age of Innocence by the idea of a telephone call as Tietjens suddenly hears himself speaking ten years earlier: 'His voice - his own voice - came to him as if from the other end of a long-distance telephone. A damn long-distance one!' (PE 281). The words he hears himself saying - 'I stand for monogamy and chastity. And for no talking about it' ( $P E$ $281,18)$ - are the echo of his previous dogmatic assertion of a unitary oneness that has been subsequently undermined by his desire for Valentine, who is the representative of an alternative female order holding open the possibility of an intersubjective existence. Significantly, Tietjens originally declares his monogamy in the context of a discussion of the lower classes, or more specifically the lower middle classes:

"The lower classes," Tietjens continued equably, "such of them as go through the secondary schools, want irregular and very transitory unions. During holidays they go together on personally conducted tours to Switzerland and such places. Wet afternoons they pass in their tiled bathrooms, slapping each other hilariously on the backs and splashing white enamel paint about. 
"Yes, a war is inevitable ... there's the multitude who mean to have bathrooms and white enamel. Millions of them; all over the world. Not merely here. And there aren't enough bathrooms and white enamel in the world to go round." (PE 19-21)

Yet, despite appearances, this is not negative comment; Tietjens describes such desires as healthy and observes: "AAll the same when the war comes it will be those little snobs who will save England, because they've the courage to know what they want and say so"' (PE 20). This sounds paradoxical: how can this mass desire of the Wellsian shopkeepers and clerks for bathrooms be both the cause of war and salvation? The answer, of course, is by the same ethical movement we have seen in Ford's earlier fiction; in which imitative fantasy is renewed and transformed even as it is broken, thus enabling the possibility of the future. In the central passages of Parade's End, Ford extends his description of such a radical transition from the individual level to that of the 'whole front' with its millions of men: 'Everyone of them is desperately afraid. But they go on. An immense blind will forces them in an effort to consummate the one decent action that humanity has to its credit of recorded history' (PE 453-4).

Ford's depiction of Tietjen's participation in the First World War, replaying his own participation, records the ultimate ethical triumph of intersubjectivity. In being stripped down to this sole activity of 'going on', Tietjens and Ford themselves were released from their former constraints and enabled to find a future. The essence of this transformation is conveyed in, and by the title of, the third volume of Parade's End: A Man Could Stand Up-:

The sergeant beside him said:

"Then a man could stand hup on an 'ill. . . You really mean to say, sir, that you think a man will be able to stand up on a bleedin' 'ill...."

$[\ldots .$.

"You're a Lincolnshire man, aren't you? You come from a Fen country. What do you want to stand up on a hill for?"

The man said:

"Ah, but you $d o$, sir!"

He added:

"You want to stand up! Take a look around ..." He struggled for expression: "Like as if you wanted to breathe deep after bein' in a stoopin' posture for a long time!"

Tietjens said:

"Well, you can do that here. With discretion. I did it just now...."

The man said: 
"You sir ... You're a law hunto yourself!" (PE 570)

Ford is right to register this pastoral exchange as the most considerable reward of Tietjens's military career because it represents a mutual exchange of ironical humility by which, in Empson's terms, the 'important' is classed with the 'lowest' in order to raise everyone's standards. Tietjens has discovered freedom while in a 'stoopin' posture' and so the act of standing necessarily expands his sphere of actions and makes him truly a law unto himself. Not only has the old patriarchal order been destroyed but meaning has also been discovered outside it: 'Feudalism was finished; its last vestiges were gone. It held no place in it for him. He was going - he was damn well going! - to make a place in it for ... A man could now stand up on a hill, so he and she could surely get into some hole together' ( $P E$ 668). The parallax shift from Ford-Marwood to Ford-Marwood-Wells is complete and Tietjens escapes the last post and the parades and is finally seen in the guise of the Wellsian (antiques) shopkeeper hero, bicycling off into the sunset to support his new family.

In Portraits from Life (1937), Ford wrote:

Mr H.G. Wells and I must have been enemies for more years than I care now to think of. And the situation is rendered more piquant by the fact that one or the other of us must by now be the doyen of English novelists - although I prefer not to discover which of us it is. At any rate in the kingdom of letters Mr Wells and I have been the leaders of opposing forces for nearly the whole of this century.

I do not think it is immodesty in a man to claim that he is a leader of forces when his military unit is indeed a unit. One may be allowed, I mean, to say that one is one's own leader ... for it is getting on for a great number of years since I could say that I had in England even a comrade in arms, so complete has been the triumph in that country of Mr Well's forces ... ${ }^{40}$

Yet he was wrong because the triumph of 'Well's forces' - most importantly, Orwell, Holden, who lived in Wells's mews flat during the Blitz and the whole intermodern project including proletarian literature - was also a vindication of his work and the real nature of the triumph was the intermodern parallax shift that both Ford and Wells represented. Žižek picks Henry James as his key literary example in The Parallax View because he thinks his unflinching attitude to the horror of deadlock provides an insight into the totality of today's world constellation, in which the parallax view 
cannot be brought together. However, the example Ford provides of how it was done after the First World War holds open an alternative model of cultural practice.

\footnotetext{
${ }^{1}$ George Orwell, 'The Proletarian Writer' [1940] in The Complete Works of George Orwell, XII, ed., Peter Davison, London: Secker \& Warburg, 2000, p.295. 'The Proletarian Writer' is the transcript of a radio discussion between Orwell and Desmond Hawkins, who was the actual speaker of the lines quoted; but as Davison observes in an editorial footnote: 'For broadcasting convenience, parts of the discussion were spoken by a participant whether or not he had generated the ideas initially.' It is my understanding that the script would have been adapted from a treatment written by Orwell.

${ }^{2}$ Virginia Woolf, 'Modern Fiction' in The Crowded Dance of Modern Life, pp.7, 9.

${ }^{3}$ Ibid., p.8.

${ }^{4}$ Slavoj Žižek, The Parallax View, Cambridge, MA and London: The MIT Press, 2006, p.4.

${ }^{5}$ See Nick Hubble, 'Review of George Orwell and the Radical Eccentrics', Textual Practice 19 (4), December 2005, 555-9.

${ }^{6}$ See Žižek's section on 'The Kantian Parallax' in Žižek, op. cit., pp.20-28.

${ }^{7}$ Ibid., pp.22-3.

${ }^{8}$ John Haffenden, William Empson: Among the Mandarins, Oxford: Oxford University Press, 2005, p.394.

${ }^{9}$ For a fuller discussion see Hubble, 'Intermodern Pastoral: William Empson and George Orwell' in David James and Philip Tew, eds, New Versions of Pastoral: Post-Romantic, Modern, and Contemporary Responses to the Tradition, Madison, Teaneck: Fairleigh Dickinson University Press/ London: Associated University Press - forthcoming 2008.

${ }^{10}$ Orwell, The Road to Wigan Pier, The Complete Works of George Orwell, V, ed., Peter Davison, London: Secker \& Warburg, 1998, p.215.

${ }^{11}$ Orwell, Coming Up for Air, The Complete Works of George Orwell, VII, ed., Peter Davison, London: Secker \& Warburg, 1998, pp.20, 247; see also Hubble, 'Intermodern Pastoral'.

${ }^{12}$ See Orwell, 'The Proletarian Writer', pp.297-9; see also Hubble, 'Intermodern Pastoral'.

${ }^{13}$ See Ford Madox Ford, 'D.H. Lawrence' in Sondra J Stang, ed., The Ford Madox Ford Reader, London: Paladin, 1987, pp.255-63.

${ }^{14}$ Max Saunders, Ford Madox Ford: A Dual Life, I, Oxford and New York: Oxford University Press, 1996, p.325.

${ }^{15}$ Hubble, 'Beyond Mimetic Englishness: Ford's English Trilogy and The Good Soldier' in Dennis Brown and Jenny Plastow, eds, Ford Madox Ford and Englishness, International Ford Madox Ford Studies, 5, Amsterdam: Rodopi, 2006, p.154.

${ }^{16}$ Ford Madox Ford, The Good Soldier, Harmondsworth: Penguin, 1988, p.227; Hubble, 'Beyond Mimetic Englishness', p.159.

${ }^{17}$ Saunders, op. cit., p. 210 .

${ }^{18}$ Ibid., pp.22, 9.

${ }^{19}$ See ibid., pp.28, 63-4, 251.

${ }^{20}$ Bernard Crick, George Orwell: A Life, Harmondsworth: Penguin, 1982, p.174.

${ }^{21}$ Ford, A Call: The Tale of Two Passions, Manchester: Carcanet, 1984, p.158. Henceforward, AC

${ }^{22}$ Cited in Saunders, op. cit., p.413.

${ }^{23}$ Ibid., p.302.

${ }^{24}$ Ibid.

${ }^{25}$ Žižek, op. cit., p.132.

${ }^{26}$ Ibid., p.138.

${ }^{27}$ Ibid., p. 126

${ }^{28}$ Ibid.

${ }^{29}$ Cited in Saunders, p.267.

30 Žižek, 129.

${ }^{31}$ Saunders, 302-3.

${ }^{32}$ Saunders, 261-2.

${ }^{33}$ Žižek, 131.

${ }^{34}$ Ibid., p.135. Žižek provides a similar reading in Did Somebody Say Totalitarianism: Five Interventions in the Misuse of a Notion, London and New York: 2001, p.12.

${ }^{35}$ Edith Wharton, The Age of Innocence, ed. Stephen Orgel, Oxford: Oxford University Press, 2006, p.96
} 
${ }^{36}$ Ford [as Daniel Chaucer], The New Humpty-Dumpty, London: The Bodley Head, 1912, pp.40, 27 , 314.

${ }^{37}$ Žižek, 128.

${ }^{38}$ Ibid., 127

${ }^{39}$ Ford, Parade's End, Harmondsworth: Penguin, 1982, p.86.

${ }^{40}$ Cited in Alan Judd, Ford Madox Ford, London: Collins, 1990, pp.237-8. 